\title{
Improving Outcome Assessment in Information Technology Program Accreditation
}

\author{
Bryan S. Goda and Charles Reynolds \\ United States Military Academy \\ West Point, NY, USA
}

\section{bryan.goda@usma.edu; charles.reynolds@usma.edu}

\section{Executive Summary}

As of March 2010, there were fourteen Information Technology programs accredited by the Accreditation Board for Engineering and Technology, known as ABET, Inc (ABET Inc. 2009). ABET Inc. is the only recognized institution for the accreditation of engineering, computing, and technology programs in the U.S. There are currently over 128 U.S. schools that offer information technology degree programs listed on the Princeton Review Website and many of these schools are preparing for, or considering undergoing, the rigors of the ABET accreditation process (Princeton Review, 2010). As a result, there is a greater need for administrators and faculty to better understand the accreditation process. To help satisfy this need, a survey of nine accredited programs was done to determine commonalities of successful programs. This paper describes the ABET program criteria and how successful programs have accomplished learning outcomes assessment.

Keywords: Accreditation, Assessment, IT Education, IT Curriculum Development

\section{Introduction}

The United States Military Academy at West Point is one of five of the service academies in the United States. Founded in 1802, it is the oldest engineering school in the U.S. West Point has an undergraduate enrollment of 4400 cadets and all of its graduates serve in the U.S. Army upon graduation. West Point has 7 accredited engineering majors and 2 accredited computing majors.

According to the Middle States Commission on Higher Education, "Accreditation is the educational community's means of self-regulation through quality assurance and improvement. The accrediting process is intended to strengthen and sustain the quality and integrity of higher education, making it worthy of public confidence Accreditation is important to prospective college students because it is an external certification of the quality of education provided" $(2010$, p. 1).

Material published as part of this publication, either on-line or in print, is copyrighted by the Informing Science Institute. Permission to make digital or paper copy of part or all of these works for personal or classroom use is granted without fee provided that the copies are not made or distributed for profit or commercial advantage AND that copies 1) bear this notice in full and 2) give the full citation on the first page. It is permissible to abstract these works so long as credit is given. To copy in all other cases or to republish or to post on a server or to redistribute to lists requires specific permission and payment of a fee. Contact Publisher@InformingScience.org to request redistribution permission.
Schools that are not accredited may not be eligible for Federal funding. Most importantly, prospective employers and graduate schools may not recognize a non-accredited program (Articlesbase, 2009).

After piloting evaluation programs in preceding years, ABET Inc. gave approval to the criteria for accrediting computing programs (ABET Inc. CAC, 
2009). These criteria include General Criteria that must be satisfied by all accredited programs in computing and specific Program. There are eight general criteria that include:

- Students

- Program objectives

- Student outcomes

- Continuous improvement

- Curriculum

- Faculty

- Facilities

- Institutional support.

The Program Criteria includes coverage of several topics specific to IT curricula. In 2009, the ABET Computing Accreditation Committee (CAC) reported that only 51\% of 95 computing programs visited in 2008-2009 received favorable ratings (Kelly, Parrish, \& Price, 2009). The report explained the most common causes of the low success rate:

1. Most IT programs are new and are seeking accreditation for the first time.

2. IT programs with faculty experience in accreditation are rare.

3. The boundaries of the IT discipline are still being defined.

The report also explained that the main focus in preparation for accreditation should be the development of learning objectives and outcomes and to assess the program outcomes. Students, curriculum, faculty, facilities, and institutional support are in place, as specified in the criteria, to achieve the outcomes.

\section{Literature Overview}

"Assessment of student learning outcomes plays an important role in educational effectiveness, improvement, and sustainability that is increasingly being recognized and required by accrediting bodies" (Buzzetto-More \& Alade, 2006, p.1). Assessment is an integral part of assuring that an educational institution meets necessary standards, as well as a crucial means of providing the evidence necessary for seeking and maintaining accreditation (Love \& Cooper, 2004).

Kellough and Kellough (1999) identified seven purposes of assessment:

1. Improve student learning;

2. Identify students' strengths and weaknesses;

3. Review, assess, and improve the effectiveness of different teaching strategies;

4. Review, assess, and improve the effectiveness of curricular programs;

5. Improve teaching effectiveness;

6. Provide useful administrative data that will expedite decision making; and

7. To communicate with stakeholders.

The most commonly used type of assessment is summative assessment, used to identify that a student has satisfied learning goals following completion of learning activities. It is an assessment of learning and summarizes the development of learners at a particular time. Formative assessment examines the development of a student during the learning process and is used in order to make adjustments. It provides information to the student about progress, strengths, and areas of improvement (Strivens et al., 2009).

The primary difference between formative and summative assessment is that in formative assessment the primary objective is to inform the instructor what are the student weak areas and to allow for the modification of instruction based on student performance (Marzano, 2006). Summa- 
tive assessment occurs at the end of learning, which means that summative assessment has less effect on student learning.

Norm referenced assessment is a method to compare individual student performance in an appropriate peer group. It is designed to sort students instead of comparing against a standard. Examples of norm referenced assessments are college entrance exams such as the Scholastic Aptitude Test (SAT), the American College Testing exam (ACT), or the Graduate Record Exam (GRE). These tests are increasingly being used in the assessment of outcomes such as the Fundamentals of Engineering Exam (FE).

Project based assessment is another strategy that can be used in the assessment of student learning where projects are assigned so a student can draw on their body of knowledge to solve a complex problem. The advantage of this type of assessment is that is shows what a student has learned and how they can apply their knowledge. Projects often force the student to research new areas outside the original course material and to work in teams as they will in the workforce.

At the last Special Interest Group for Information Technology Educators (SIGITE) conference, the most popular birds of a feather session discussed IT accreditation. Attendees concluded that the assessment bar had been raised and past practices are now inadequate to meet current assessment needs. The dramatic rise in the number of IT programs has created a vacuum in the sharing of best IT assessment practices. Creating efficient and innovative ways to do assessment will make an accreditation visit less taxing and improve the overall Next General Review success rate for IT programs (personal communication, October 28, 2009). Conference attendees agreed that there was little if any research done on IT program accreditation trends and many new programs were still searching for any lessons learned. The nine accredited IT programs at the time were sent a survey in 2009 and results from five respondents are summarized in this article, which should help future IT programs in their assessment efforts.

\section{Outcome Assessment}

There were 9 ABET accredited IT programs in 2008. For this study, a survey consisting of 8 questions was sent via email to all 9 ABET accredited programs. Seven of the 9 programs responded.

The first question considered assessment of student learning outcomes. The question: "What do you recommend in the assessment of outcomes?" was posed and three sample responses follow.

1. "The key goal is to have a clear process for continuous improvement of the curriculum and the content that is assessed with both direct and indirect measures. We survey students about their perception of mastery of the outcomes on every course offering, each course is analyzed by the instructor and audited by the program chair. We also have a table that maps direct assessments in the course to the course outcomes and program outcomes along with the direct measures applied to assess the outcomes. You must show that you have a well thought out process and demonstrate that you follow it."

2. "Many institutions tend to think that they need to make major changes to the curriculum in order to accommodate assessment. I have found that most schools go through three steps and which step they are on tends to indicate how mature their assessment process is. The first step is to modify their assessment process. It often takes two complete cycles to actually get a good, working and sustainable process in place. The second step is to make major curriculum changes such as creating new courses. The final step (the mature one) is to make minor changes to improve the program. For example, if the results of the "functioning on a team" outcome is not as good as expected, they might introduce one team programming project in an earlier programming course where all work had been individually done previously or they might take a day of class to actually instruct the stu- 
dents on how to build an effective team. Another thing that many schools fail to do is to establish an a priori level of expectation before they start collecting data. Without this expectation, it is difficult to determine whether students are meeting the expectation the program has of them."

3. "For objectives we use standard job placement rates, alumni surveys, etc. For outcomes we map our outcomes to which courses they map to in the curriculum (or through coop/senior project). Within those courses we then measure outcomes based on student success with specific projects or questions on exams. We measure outcome accomplishment every two years. We have got great data from our co-op surveys, which are surveys that employers fill out about co-op students at the end of each term. Our program requires coop. This assessment by employers has been a great vehicle for us because we can measure student success as sophomore students through seniors. We are still working on a follow-up of the assessment. Right now we leave it in the hands of the individual faculty to address any outcomes that are not met within their courses. We hope to create a digital repository to easily scan how we are doing at meeting our outcomes. We also hope to have the assessment be a formal part of a faculty member's annual evaluation (that they did the assessments, not if students met outcomes)."

Although there are many ways to do assessment, successful programs have a working system of assessment that demonstrates that a program is achieving its objectives and outcomes or is steadily moving in that direction. This requires that an assortment of assessment tools be utilized, such as surveys, interviews, and examinations developed by assessors other than the instructors. A more robust assessment system means more work for faculty members, so any assessment system must strike a delicate balance between the effort required and the quality of the results. New programs will have little data to support the accomplishment of objectives since these are measured after graduation, so a robust system for measuring outcomes and a planned system for the measurement of objectives must suffice (Kelly et al., 2009).

Information technology programs design their program outcomes using criteria (a)-(i) for computing programs and (j)-(n) for IT specific programs (ABET Inc. CAC, 2009). Students in both engineering and computing programs take math, science, English, history, and ethics courses as part of a general education program from academic departments other than the major department. Other institutions have found that the assessment of general education learning outcomes can create a central core of values (Gibralter \& Cepriano, 2006). Not surprisingly, there are several of the CAC (a)-(i) criteria that are not discipline-specific and that address general education:

(a) An ability to apply knowledge of computing and mathematics appropriate to the discipline

(b) An ability to analyze a problem, and identify and define the computing requirements appropriate to its solution

(c) An ability to design, implement, and evaluate a computer-based system, process, component, or program to meet desired needs

(d) An ability to function effectively on teams to accomplish a common goal

(e) An understanding of professional, ethical, legal, security and social issues and responsibilities

(f) An ability to communicate effectively with a range of audiences

(g) An ability to analyze the local and global impact of computing on individuals, organizations, and society

(h) Recognition of the need for and an ability to engage in continuing professional development

(i) An ability to use current techniques, skills, and tools necessary for computing practice 
Compare these to selected engineering criteria from Criteria for Accrediting Engineering Programs (ABET Inc. EAC, 2008):

(a) An ability to apply knowledge of mathematics, science, and engineering

(b) An ability to design and conduct experiments, as well as to analyze and interpret data

(c) An ability to design a system, component, or process to meet desired needs within realistic constraints such as economic, environmental, social, political, ethical, health and safety

(d) An ability to function on multidisciplinary teams

(e) An ability to identify, formulate, and solve engineering problems

(f) An understanding of professional and ethical responsibility

(g) An ability to communicate effectively

(h) The broad education necessary to understand the impact of engineering solutions in a global, economic, environmental, and societal context

(i) A recognition of the need for, and an ability to engage in life-long learning

(j) A knowledge of contemporary issues

(k) An ability to use the techniques, skills, and modern engineering tools necessary for engineering practice

All computing and engineering programs use ABET criteria when designing their program outcomes. Most programs have a shared general education curriculum with some form of an assessment program in place. West Point had ten programs going through accreditation review at the same time. As a result, a common committee was formed to gather assessment results from the shared general education program. Committee members examined the general education courses for contributions to the generic criteria noted above.

Once this assessment data had been collected, a method was developed to provide a concise and easy way to summarize the data. It was decided to display this data on a Web site because of the ease of distribution. The common committee then assigned a Bloom's Taxonomy of Educational Objectives (Bloom, Mesia, \& Krathwohl, 1956) from 1-6 evaluating the contribution of each course to the general criteria shown in Figure 1.

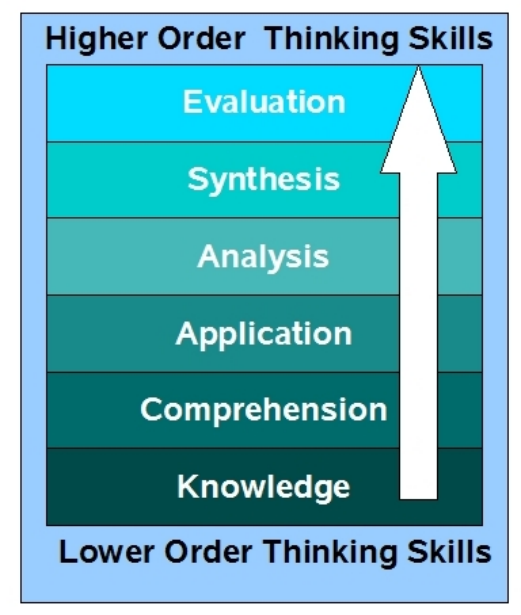

Figure 1: Bloom's Taxonomy of Educational Objectives

Level 1 is the lowest level and corresponds to basic knowledge, such as being able to define and recognize. Level 3 is the application level where students can demonstrate, solve and use knowledge. This is the most common level of course evaluation as shown in the examples in Table 1 . 
Level 6 is the highest level where students can make judgments and critically evaluate outcomes. Level 6 relates to higher order thinking.

To provide more information, the Web site was designed to amplify the details behind the awarding of the Bloom rating number if the user mouse hovers over the Bloom number. To provide more detailed information, each course was hyper-linked to its syllabus and the course description hyper-linked to its catalog description. Each of West Point's 10 programs used this Web site to provide an assessment of the incoming skills that students are expected to possess upon entrance into their respective programs. Another benefit of the matrix is that it highlights which courses teach skills such as writing, mathematics, working in a team, and ethics. The table has been compressed to show the outcomes $(\mathrm{a}, \mathrm{b}, \mathrm{f})$ that relate to mathematics, science, and communications skills.

Table 1: Core Courses Mapped to CAC Criteria

\begin{tabular}{|c|c|c|c|c|c|}
\hline $\begin{array}{l}\text { Course } \\
\text { Number }\end{array}$ & $\begin{array}{l}\text { Course } \\
\text { Description }\end{array}$ & Credits & $\begin{array}{l}\text { a) Knowledge of Math, } \\
\text { Science and } \\
\text { Engineering }\end{array}$ & $\begin{array}{l}\text { b) Ability to } \\
\text { Analyze a } \\
\text { problem }\end{array}$ & $\begin{array}{l}\text { f) Ability to } \\
\text { Communicate }\end{array}$ \\
\hline EN101 & Composition & 3 & 3 & & 3 \\
\hline MA103 & $\begin{array}{l}\text { Discrete } \\
\text { Dynamical } \\
\text { Systems } \\
\text { /Intro to } \\
\text { Calculus }\end{array}$ & 4 & $\begin{array}{l}\text { Projects, homework, } \\
\text { and assignments require } \\
\text { cadets to apply course } \\
\text { concepts to specific } \\
\text { applications } \\
\text { Daily board problems, } \\
\text { quizzes, and WPRs } \\
\text { require cadets to dem- } \\
\text { onstrate competency in } \\
\text { using functions, matri- } \\
\text { ces and difference } \\
\text { equations }\end{array}$ & 4 & \\
\hline CH101 & $\begin{array}{l}\text { General } \\
\text { Chemistry I }\end{array}$ & 3 & 2 & $\begin{array}{c}3 \text { Extensive lab } \\
\text { program where } \\
\text { cadets "conduct" } \\
62 \text {-hour experi- } \\
\text { ments } \\
\text { In all experiments, } \\
\text { cadets are re- } \\
\text { quired to analyze } \\
\text { and discuss their } \\
\text { data } \\
\text { Focus of this in- } \\
\text { troductory lab } \\
\text { program is not on } \\
\text { designing experi- } \\
\text { ments }\end{array}$ & \\
\hline
\end{tabular}

While this table is not a substitute for direct measures, it does provide waypoints that track student progress. Incoming major students are expected to have a set of skills that are necessary for the accomplishment of the program outcomes. If, during the assessment process, certain skills are found inadequate, this feedback can be given to the general education program. 
One of the first exercises done at accreditation training is the creation of a list of program outcomes. This list must logically map to the generic and IT program outcomes (a) - (n) (ABET Inc. CAC 2009).

Embedded indicators are specific measures that can be taken to assess student performance such as performance on an individual test question (Barnetson \& Cutright, 2000). It has become readily apparent that these embedded indicators are too finely grained to be used in assessing program outcome achievement. Most embedded indicators take the form of a test question that shows a performance measure on a single topic. One idea is to use the Association for Computing Machinery (ACM) Special Interest Group in Information Technology Education (SIGITE) body of knowledge (BOK) as the intermediate level between the program outcomes and the embedded indicators (Lunt et al., 2008). The BOK is a document that specifies the topics to be included in the core of an IT program. It lists the suggested minimum hours, although most programs will exceed the suggested minimum. The BOK can help an IT program identify where it could be missing topical coverage or not providing enough depth. To this end, a systematic and cost effective method to track topic coverage is needed.

There are several advantages to mapping embedded indicators to the BOK rather than to a list of program outcomes:

1. The BOK is arranged by topical area and recommended hours. It is easier to map embedded indicators to the BOK than to program outcomes.

2. By mapping the BOK areas to the program outcomes, it is easier to collect several embedded indicators from different subject areas.

3. Instructors find it easier to map their course to the BOK, rather than a list of program outcomes.

4. It is easier to compare suggested hours with actual hours of instruction in a program to identify potentially weak areas that require more coverage.

Table 2 depicts an example of a way to track program content against the BOK. Across the top, the various courses are listed and on the side the various topics in the BOK are listed. Since the BOK has a detailed section that describes topics that should be covered, an instructor can determine how many hours of each topic to cover. Once each course (column) has been evaluated against the BOK (rows), the rows can be summed to determine the program's coverage. The suggested times can be compared to the program totals to determine if there is an area missing or not covered in sufficient depth. The table also reveals the focus of each course and the rows can be color coded to indicate groupings.

Once completed, the topic areas can be mapped to specific program outcomes. For example, ITF1 Pervasive Themes in IT consists of a minimum of 17 hours in such areas as professionalism, interpersonal skills, human computer interaction, and information assurance. Suppose the program wishes to assess the oral and written communication learning outcome. Topic areas will be covered in more than one course, so the matrix makes it easier to identify the embedded indicators that support an outcome due to the smaller granularity of an embedded indicator versus the broad scope of a program outcome. The BOK can provide this framework and can help organize an indicator to support several outcomes. An outcome can list the appropriate topics that apply and it makes it easier to identify areas to seek measurement data. 
Table 2: Sample BOK/Course Coverage Spreadsheet (not all courses included)

\begin{tabular}{|c|c|c|c|c|c|c|c|}
\hline & Topic & $\begin{array}{l}\text { Suggested } \\
\text { Time }\end{array}$ & $\begin{array}{l}\text { Our } \\
\text { Time }\end{array}$ & & & & \\
\hline & Information Technology Fundamentals (33 hrs) & & & 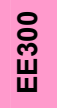 & $\begin{array}{l}\text { 号 } \\
\text { 岃 }\end{array}$ & 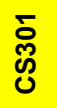 & $\begin{array}{l}\text { 유 } \\
\text { ఝ్ర }\end{array}$ \\
\hline ITF1 & Pervasive Themes in IT & $17 \mathrm{hrs}$ & 19 & 1 & & 2 & 2 \\
\hline ITF2 & Organizational Issues & $6 \mathrm{hrs}$ & 8 & & & 1 & \\
\hline ITF3 & History of IT & $3 \mathrm{hrs}$ & 3 & & & 1 & \\
\hline ITF4 & IT and Its Related and Informing Disciplines & $3 \mathrm{hrs}$ & 5 & 1 & 1 & 1 & \\
\hline ITF5 & Application Domains & $2 \mathrm{hrs}$ & 5 & & 3 & & \\
\hline \multirow[t]{2}{*}{ ITF6 } & Applications of Math and Statistics to IT & $2 \mathrm{hrs}$ & 6 & 1 & & & \\
\hline & Human Computer Interaction (20 hrs) & & & & & & \\
\hline $\mathrm{HCl} 1$ & Human Factors & $6 \mathrm{hrs}$ & 8 & & & 1 & 1 \\
\hline $\mathrm{HCl} 2$ & Aspects of Applications Domains & $3 \mathrm{hrs}$ & 6 & & & & 1 \\
\hline $\mathrm{HCl} 3$ & Human Centered Evaluation & $3 \mathrm{hrs}$ & 6 & & & & 1 \\
\hline $\mathrm{HCl} 4$ & Developing Effective Interfaces & $3 \mathrm{hrs}$ & 5 & & & & \\
\hline $\mathrm{HCl} 5$ & Accessibility & $2 \mathrm{hrs}$ & 1 & & & & \\
\hline $\mathrm{HCl} 6$ & Emerging Technologies & $2 \mathrm{hrs}$ & 4 & & 2 & & \\
\hline $\mathrm{HCl} 7$ & Human Centered Software Development & $1 \mathrm{hr}$ & 2 & & 1 & & \\
\hline
\end{tabular}

The survey distributed in 2008 to the existing ABET accredited IT programs asked the double barreled question: "How closely does your program resemble the ACM SIGITE Body of Knowledge 2005 or 2008 ? Do you track how close your program is to the BOK?" Select responses follow.

1. "It is very close to 2005 , we build our program based on the drafts of this. We need to look more closely at 2008 to be sure we are still in line with the BOK."

2. "Pretty closely. We spent a lot of time working on both the curriculum and our own program."

3. "We do not track how close our program is to the ACM Body of Knowledge although we do try to make sure we are covering the main topics. The major reason for this is that our first graduates were completing through the program before this information was available. Our program actually stresses Web, database, networks and security with security becoming much more important for our graduates."

\section{Outcome and Objective Worksheets}

To tie program outcomes to the BOK, courses, and indicators a worksheet was created during and assessment workshop (Lawson, Lidtke, \& Price, 2007). This is shown for one program outcome in Table 3. As data is collected, it is added to the worksheet until enough information is present to perform an assessment of the level of achievement of the program outcome. Showing the ABET evaluator a worksheet for each of program outcome makes it easy to show the data that has been collected, the impact of the data, and what actions have been taken. The idea is not to produce 
volumes of data, but to summarize data in a way that is applicable and concise. The results of the data collection, and actions taken, show a progression of how a program moves through the assessment process.

Table 3: Sample Outcome Worksheet for Evaluate Effective User Interaction Designs

\begin{tabular}{|c|c|c|c|}
\hline $\begin{array}{l}\text { Program } \\
\text { Outcome }\end{array}$ & Course & Assessment Methods & Maps to IT Curriculum \\
\hline $\begin{array}{l}\text { User } \\
\text { Interaction } \\
\text { Design }\end{array}$ & $\begin{array}{l}\text { CS350 } \\
\text { CS473 } \\
\text { CS486 } \\
\text { EE450 } \\
\text { IT105 } \\
\text { IT305 } \\
\text { IT383 } \\
\text { IT401 }\end{array}$ & $\begin{array}{l}\text { Website Project, Course Summary } \\
\text { Project, Course Summary } \\
\text { Exam Question, Course Summary } \\
\text { Design Project } \\
\text { Website Project } \\
\text { Web-portal Project, Course Summary } \\
\text { Project, Exam, Course Summary } \\
\text { Design Project, Course Summary }\end{array}$ & $\begin{array}{l}\text { Human Computer Interaction } \\
\text { HCI1 Human Factors } \\
\text { HCI2 Aspects of App. Domains } \\
\text { HCI3 Human Centered Evaluation } \\
\text { HCI4 Dev.Effective Interfaces } \\
\text { HCI5 Accessibility } \\
\text { HCI6 Emerging Technologies HCI7 } \\
\text { Human Centered Software } \\
\text { System Integration and Architecture } \\
\text { SIA1 Requirements } \\
\text { SIA2 Acquisition/Sourcing } \\
\text { SIA3 Integration } \\
\text { SIA4 Project Management } \\
\text { SIA5 Testing and QA } \\
\text { SIA6 Organizational Context }\end{array}$ \\
\hline
\end{tabular}

Results AY 2006: IT305 Web-portal Project: 98\% (8 students)

Results AY 2007: IT305 Web-portal Project: 87\% (17 students)

CS350 Semester Project Website: 94\% (11 students)

Results AY 2008: EE450 Final Design Project 87\% (10 students), End of Course Survey Question: If you have to learn a new piece of software that requires you to program it, how confident are you that you can use the software to solve your problem. 3.88 ( 3 = neutral, $4=$ Agree, $5=$ Strongly Agree) 26 students Actions AY 2007: Improve Student AIAD Experiences. IT401/402 Netsmart design project. Actions AY 2008: Outcomes Assessment - We are meeting Outcome 7 based on the series of designs our students progress through their program of instruction. The year-long project in IT401/402 gives our students to work with outside agencies in developing a user specific design. Their designs are demonstrated during projects day and at student conferences such as the ASEE Region I conference.

The survey distributed in 2008 to the existing ABET accredited IT programs asked the respondents to comment on future trends. Specifically, participants were asked "What future trends do you see in IT accreditation?" and two sample responses follow.

1. "There is more and more concern about the continuous improvement system and how it is executed. You really need to know what you want to do, document it, figure out how to measure it, and active work to improve all aspects of the process: the plan, measures, and curriculum with the teaching."

2. "I personally think the field will become more specialized and that students will get a taste of all the pillars of IT but have a concentration in one area such as cyber security. Since IT is the more applied area of computer science, I think students will be drawn to this area more than to the traditional computer science area. In terms of accreditation, this will mean that the IT program evaluators are going to have to be more flexible and consider where students are getting jobs to see if the program is producing the types of graduates with the necessary knowledge to succeed." 


\section{Limitations}

There are many limitations in our research. We are dealing with a very small sample of 7 responding programs that represented the 9 ABET accredited IT programs in the United States that existed in 2008. A limited number of open-ended research questions were asked making the data unquantifiable. Further, flaws in question design existed. At the same time, the information provided in this paper provides a foray into an area that has not been sufficiently covered in the literature.

\section{Conclusion}

This paper provided commentary about outcomes assessment from several ABET accredited IT programs as well as offered information on the development of learning outcomes, the conduction of curriculum alignment, and the identification of existing assessments for schools in the beginning stages of the ABET accreditation process. With over 128 IT programs offered in the United States, and with the growing popularity of program accreditation, the number of schools seeking ABET accreditation is posed to increase dramatically in coming years. While many curriculum areas such as education and business have been engaged in assessment and accreditation for some time, IT is an area new to the process. As a result, the programs under consideration have fairly young assessment programs that have not yet matured to the point that they have collected, analyzed, and made changes based upon student learning outcomes assessment data. Continued research needs to be done in this area in order to better inform the IT education community.

\section{References}

ABET Inc. (2009). Accredited program search. Retrieved March 2, 2010, from http://www.abet.org/AccredProgramSearch/AccreditationSearch.aspx

ABET Inc. CAC (2009). Criteria for accrediting computing programs. Effective for evaluations during the 2009- 2010 Accreditation Cycle. Retrieved March 3, 2010, from http://www.abet.org/Linked\%20Documents-UPDATE/Criteria\%20and\%20PP/C001\%200910\%20CAC $\% 20$ Criteria\%2012-01-08.pdf

ABET Inc. EAC (2008). Criteria for accrediting engineering programs. Retrieved March 4, 2010, from http://www.abet.org/Linked\%20Documents-UPDATE/Criteria\%20and\%20PP/E001\%200708\%20EAC\%20Criteria\%2011-15-06.pdf

Articlesbase. (2009). Why is accreditation important while selecting a college? Retrieved March 3, 2010, from http://www.articlesbase.com/college-and-university-articles/why-is-accreditation-importantwhile-selecting-a-college-964141.html

Barnetson, B., \& Cutright, M. (2000). Performance indicators as conceptual technologies. Higher Education, 40(3), 277-292.

Bloom, B., Mesia, B. \& Krathwohl, D. (1956). Taxonomy of educational objectives: The cognitive domain. New York: David McKay Publishing Company.

Buzzetto-More, N., \& Alade, A. (2006). Best practices in e-assessment. Journal of Information Technology Education, 5, 251-269. Retrieved from http://www.jite.org/documents/Vol5/v5p251269Buzzetto152.pdf

Gibralter, J., \& Cepriano, L. (2006). General education assessment at Farmingdale State University: Creating a central core of educational values. Assessment Update, 18(1), 8-9.

Kellough, R. D., \& Kellough, N. G. (1999). Secondary school teaching: A guide to methods and resources: Planning for competence. Upper Saddle River, New Jersey: Prentice Hall. 
Kelly, D., Parrish, A., \& Price, A. (2009). Computing Accreditation Commission Plenary Session. Retrieved March 4, 2010, from http://www.abet.org/Linked\%20Documents-UPDATE/Presentations/09CAC\%20Commission\%20Summit.pdf

Lawson, E., Lidtke, D. K., \& Price, B. (2007). Information technology accreditation activities. Outcome worksheets. Retrieved March 2, 2010, from http://www.utexas.edu/provost/sacs/educationalprograms.html\#worksheets

Love, T. \& Cooper, T. (2004). Designing online information systems for portfolio-based assessment: Design criteria and heuristics. Journal of Information Technology Education, 3, 65-81. Retrieved March 4, 2010, from http://jite.org/documents/Vol3/v3p065-081-127.pdf

Lunt, B., Ekstrom, J., Gorka, S., Kmali, R., Lawson, E., LeBlanc, R., et al. (2008). ACM computing curricula, Information technology volume. Retrieved March 2, 2010, from http://www.acm.org//education/curricula/IT2008\%20Curriculum.pdf

Marzano, R. (2006). Classroom assessments and grading that work. Alexandria, VA: Association for Supervision and Curriculum Development

Middle States Commission on Higher Education. (2010). Institutional responsibilities in the accreditation process. Retrieved January 18, 2010, from http://www.msche.org/?Nav1=POLICIES\&Nav2=INDEX

Princeton Review. (2010). College majors. Retrieved 3/10/10 from: http://www.princetonreview.com/majors.aspx?uidbadge $=\% 07$

Strivens, J., Baume, D., Grant, S., Owen, C., Ward, R., \& Nicol, D. (2009). The role of e-portfolios in formative and summative assessment. Retrieved March 5, 2010, from http://www.jisc.ac.uk/whatwedo/programmes/elearning/eportfolios/studyontheroleofeportfolios.aspx

\section{Biographies}

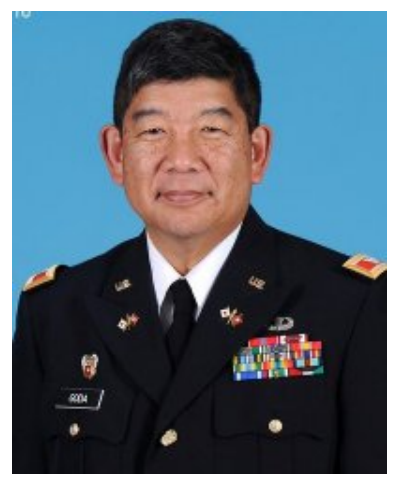

COL Bryan Goda is an Associate Professor with the Department of Electrical Engineering and Computer Science at the United States Military Academy at West Point. He is the IT program director and cochair of the USMA ABET Committee. He holds a Ph.D. in computer enginnering from Rensselaer Polytechinic Institute and a Masters of Strategic Studies from the Army War College. He has held command positions from platoon leader up to battalion commander. His interests are in IT education and field programmable gate arrays.

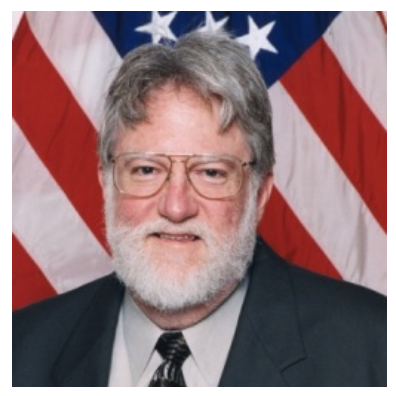

Dr. Charles W. Reynolds is Professor with the Department of Electrical Engineering and Computer Science at the United States Military Academy at West Point. He has 30 years experience in Computer Science as an educator and an administrator. He has led the design and implementation of innovative curricula in both undergraduate and graduate computer science, in information technology, and in information security. His interests are in innovative curriculum design. 